\title{
Device Tipped Over
}

National Cancer Institute

\section{Source}

National Cancer Institute. Device Tipped Over. NCI Thesaurus. Code C62921.

Problem associated with the inability of the device to stay in an upright position. 